\title{
General Toxicity screening of Royleanone derivatives using an Artemia salina model
}

\author{
Avaliação da toxicidade geral de derivados de Roileanonas pelo ensaio de letalidade de Artemia \\ salina
}

\author{
Epole Ntungwe ${ }^{1,2}$, Vera M. S. Isca ${ }^{1,3}$, Ana María Díaz-Lanza ${ }^{2}$, Carlos A. M. Afonso ${ }^{3}$, Patrícia Rijo ${ }^{1,3^{*}}$ \\ ${ }^{1}$ CBIOS - Center Research for Biosciences \& Health Technologies, Lisbon, Portugal \\ ${ }^{2}$ Department of Biomedical Sciences, Faculty of Pharmacy, University of Alcalá, Spain \\ ${ }_{3}^{3}$ Med.ULisboa, Faculdade de Farmácia da Universidade de Lisboa, Portugal \\ *corresponding author: patricia.rijo@ulusofona.pt
}

\begin{abstract}
Cancer is the second leading cause of death globally. World Health Organization recorded an estimated 9.6 million deaths attributed to cancer in 2018. There is an urgent need for new anticancer drugs with novel modes of action. Natural products remain a valuable source for the identification and development of novel treatment options for cancer. Plectranthus species are well-known medicinal species used extensively for the treatment of different illnesses. These species are rich in diterpenoids which are reported to be responsible for various pharmacological activities including cytotoxic activities. Brine shrimp (Artemia salina) is broadly used in lethality studies and this model is a convenient starting point for cytotoxicity study when screening for general toxicity of natural products. This assay is based on their ability to kill a laboratory cultured nauplii. In this work, we report the general toxicity of some derivatives from 6,7-dehydroroyleanone (1) and $7 \alpha$-acetoxy-6 $\beta$-hydroxyroyleanone (2) compounds. The A. salina bioassay is a simple, rapid, and low-cost test, and is very useful for preliminary assessment of general toxicity in natural products thereby guiding the determination of possible biological activities.
\end{abstract}

Keywords: Artemia salina, general toxicity, Royleanone, Plectranthus

\begin{abstract}
Resumo
O cancro é a segunda principal causa de morte no mundo, A Organização Mundial da Saúde registou cerca de 9,6 milhões de mortes atribuídas ao cancro em 2018. Assim existe uma grande urgência por novos fármacos anticancerígenos. Os produtos naturais continuam a ser uma importante fonte para a identificação e desenvolvimento de novos tratamentos para o cancro. O género Plectranthus engloba espécies de plantas bem conhecidas pelas suas propriedades medicinais e amplamente utilizadas no tratamento de algumas doenças. Estas plantas são ricas em diterpenóides, compostos estes que apresentam diversas atividades farmacológicas interessantes, incluindo efeitos citotóxicos. O camarão marinho (Artemia salina) é amplamente utilizado em estudos de letalidade e é um ponto de partida vantajoso para a pesquisa de toxicidade geral de produtos naturais. Este ensaio é baseado na capacidade que os produtos naturais apresentam para matar náuplios criados em laboratório. Neste trabalho relatamos a toxicidade geral de alguns derivados preparados a partir dos compostos 6,7-dehidroroileanona (1) e 7 $\alpha$-acetoxi-6 $\beta$-hidroxiroileanona (2). O bioensaio de $A$. salina é um teste simples, rápido e de baixo custo, muito útil para a avaliação preliminar da toxicidade geral de produtos naturais, orientando assim para possíveis atividades biológicas.
\end{abstract}

Palavras-chave: Artemia salina, toxicidade geral, Roileanonas, Plectranthus 


\section{Introduction}

During the past three decades, there has been significant progress in both the understanding and treatment of cancer. However, cancer remains the second leading cause of non-communicable disease deaths in the world. In 2018, there were over 18 million new cancer cases and approximately 10 million people died from the disease globally $(1,2)$.

Medicinal plants are considered potential sources for drug development and many novel products. Natural products play a relevant role in cancer therapy today. Substantial numbers of anticancer agents used in the clinic are either natural or derived from natural products from various sources such as plants, animals, and microorganisms (also of marine origin) $(3,4)$. During the last few decades, a wide range of cytotoxic agents were discovered from plants, and some of these are used as anti-cancer drugs. Paclitaxel (Taxol), for example, one of the most known chemotherapy drugs of natural origin, was derived from the bark of Taxus brevifolia and is one of the most active cancer chemotherapeutic drugs (5).

Artemia salina, commonly known as brine shrimp, is a tiny halophilic invertebrate belonging to the Phylum Arthropoda and Subphylum Crustacean, and play an important role in saline aquatic and marine ecosystems. In addition to usage as feedstuff in aquaculture, it is also highly valued for its larvae's application in toxicity detection (6). A. salina has gained popularity as a test organism for short-term toxicity testing because of its ease of culture, short generation time, and cosmopolitan distribution (7). In addition, its dormant brine shrimp eggs remain viable for many years and are therefore a suitable biological source (8). Other advantages of using brine shrimp in toxicity testing include (i) rapidity (i.e. $28-72 \mathrm{~h}$ from hatching to the first endpoint),(ii) cost-effectiveness, (iii) the availability of nauplii hatched from commercial durable cysts (eggs) (i.e., homogeneity of the population, availability allyear-round without the necessity of culturing) (9). Its use as a test organism is based on cellular mechanisms that may occur via necrosis, characterized by loss of membrane integrity, death of cell or apoptosis, a genetic program of controlled cell death (10). The significant correlation between the brine shrimp assay and in vitro growth inhibition of human solid tumor cell lines demonstrated by the National Cancer Institute (NCI, USA) further boosts the use of A. salina for general toxicity testing (11-14). This correlation is significant because it shows the value of this bioassay as a pre-

\section{Introdução}

Durante as últimas três décadas, houve um progresso significativo na compreensão e tratamento do cancro. No entanto, o cancro continua a ser a segunda causa de morte por doenças não transmissíveis no mundo. Em 2018, havia mais de 18 milhões de novos casos de cancro e aproximadamente 10 milhões de pessoas morreram da doença, em todo o mundo $(1,2)$.

As plantas medicinais são importantes fontes de obtenção no desenvolvimento de novos medicamentos e produtos. Os produtos naturais desempenham um papel relevante no tratamento do cancro, com um número substancial de agentes anticancerígenos, de uso clínico atual, provenientes de origem natural ou derivados de produtos naturais, de várias fontes, como plantas, animais e microrganismos (também de origem marinha) $(3,4)$. Durante as últimas décadas, uma vasta gama de agentes citotóxicos foi descoberta em plantas, alguns dos quais são utilizados atualmente no tratamento do cancro. O paclitaxel (Taxol), por exemplo, obtido a partir da casca de Taxus brevifolia, é um dos quimioterápicos mais conhecidos de origem natural em quimioterapia e dos mais ativos (5).

Artemia salina, popularmente conhecido como artémia, é um minúsculo invertebrado halófilo pertencente ao Filo Arthropoda e Subfilo Crustáceo, que desempenha um papel importante nos ecossistemas salinos aquáticos. Além do seu uso como alimento na aquicultura, também é altamente valorizado pelo seu uso de larvas na avaliação da toxicidade geral (6). O uso de $A$. salina ganhou enfase em estudos de triagem de toxicidade, de curto prazo. Isso deve-se à sua facilidade de cultura, curto tempo de geração e distribuição cosmopolita (7). Além disso, os ovos de artémia permanecem viáveis por muitos anos e são, portanto, uma fonte biológica adequada (8). Outras vantagens do uso de artémia em testes de toxicidade incluem: (i) rapidez (ou seja, 28-72 $\mathrm{h}$ desde a eclosão do ovo até o primeiro ponto final); (ii) custo-benefício; (iii) a disponibilidade de náuplios nascidos de cistos duráveis comerciais (ovos) (ou seja, homogeneidade da população e disponibilidade durante todo o ano, sem a necessidade de cultivo) (9). O seu uso como organismo-teste é baseado em mecanismos celulares que podem ocorrer via necrose, caracterizada pela perda da integridade da membrana, morte celular ou apoptose, programa genético de morte celular controlada (10). O National Cancer Institute (NCI, EUA) evidenciou uma correlação significativa entre o ensaio de artémia e a inibição do crescimento in vitro de linhas de células tumorais sólidas humanas, 
screening tool for antitumor drug research (15-17). In the present study, we evaluated the general toxicity of 6,7-dehydroroyleanone (1) and $7 \alpha$-acetoxy-6 $\beta$ hydroxyroyleanone (2) derivatives using the $A$. salina model.

\section{Materials and Methods}

\section{Plant Material}

The plant materials, P. madagascarensis Benth. and $P$. grandidentatus Gürke were cultivated in Parque Botânico da Tapada da Ajuda (Instituto Superior Agrário, Lisbon, Portugal) from cuttings obtained from the Kirstenbosch National Botanical Garden (Cape Town, South Africa). The extraction and isolation processes of compounds $\mathbf{1}$ and $\mathbf{2}$ (Figure 1) were performed according to Garcia C. et al., 2018 (19) and Bernardes C.E.S. et $a l, 2018$ (20), respectively.

\section{Reaction Procedures}

The reactions, purification, identification, and stability of royleanone derivatives were carried out and previously reported in the study of Garcia et al. 2020 (21), Schemes 1 and 2. o que apoia fortemente o uso do modelo de $A$. salina em testes de toxicidade geral (11-14). Isso é significativo porque mostra o valor deste bioensaio como uma ferramenta de pré-triagem para a pesquisa de fármacos antitumorais (15-18). No presente estudo, a toxicidade geral de dezassete derivados obtidos a partir de 6,7-dehidroroileanona (1) e de $7 \alpha$-acetoxi$6 \beta$-hidroxiroileanona (2) foi avaliada no ensaio de letalidade de $A$. salina.

\section{Materiais e Metodos}

\section{Material vegetal}

As plantas P. madagascarensis Benth e $P$. grandidentatus Gürke foram cultivadas no Parque Botânico da Tapada da Ajuda (Instituto Superior Agrário, Lisbon, Portugal) a partir de estacas obtidas do Kirstenbosch National Botanical Garden (Cidade do Cabo, África do Sul). Os processos de isolamento e extração dos produtos naturais 1 e 2 (Figura 1) foram realizados segundo Garcia C. et al., 2018 (19) e Bernardes C.E.S. et al, 2018 (20), respetivamente.

\section{Procedimentos das Reações}

As reações e a purificação, identificação e estabilidade dos derivados de roileanona foram realizadas no estudo de Garcia et al. 2020 (21), Esquemas 1 e 2.

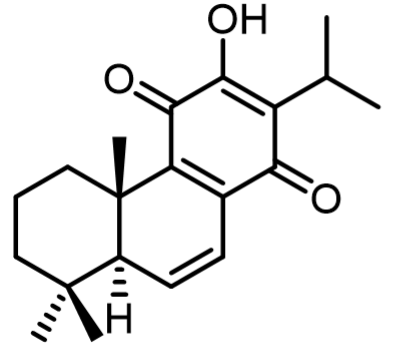

1

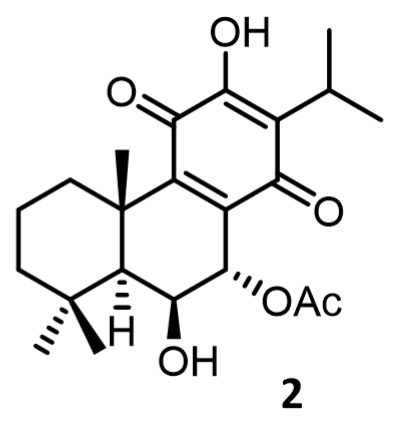

Figure 1 -6,7-dehydroroyleanone (1) and $7 \alpha$-acetoxy-6 $\beta$-hydroxyroyleanone (2)

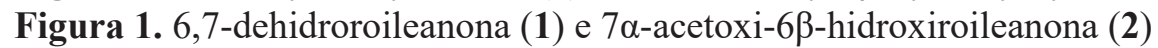




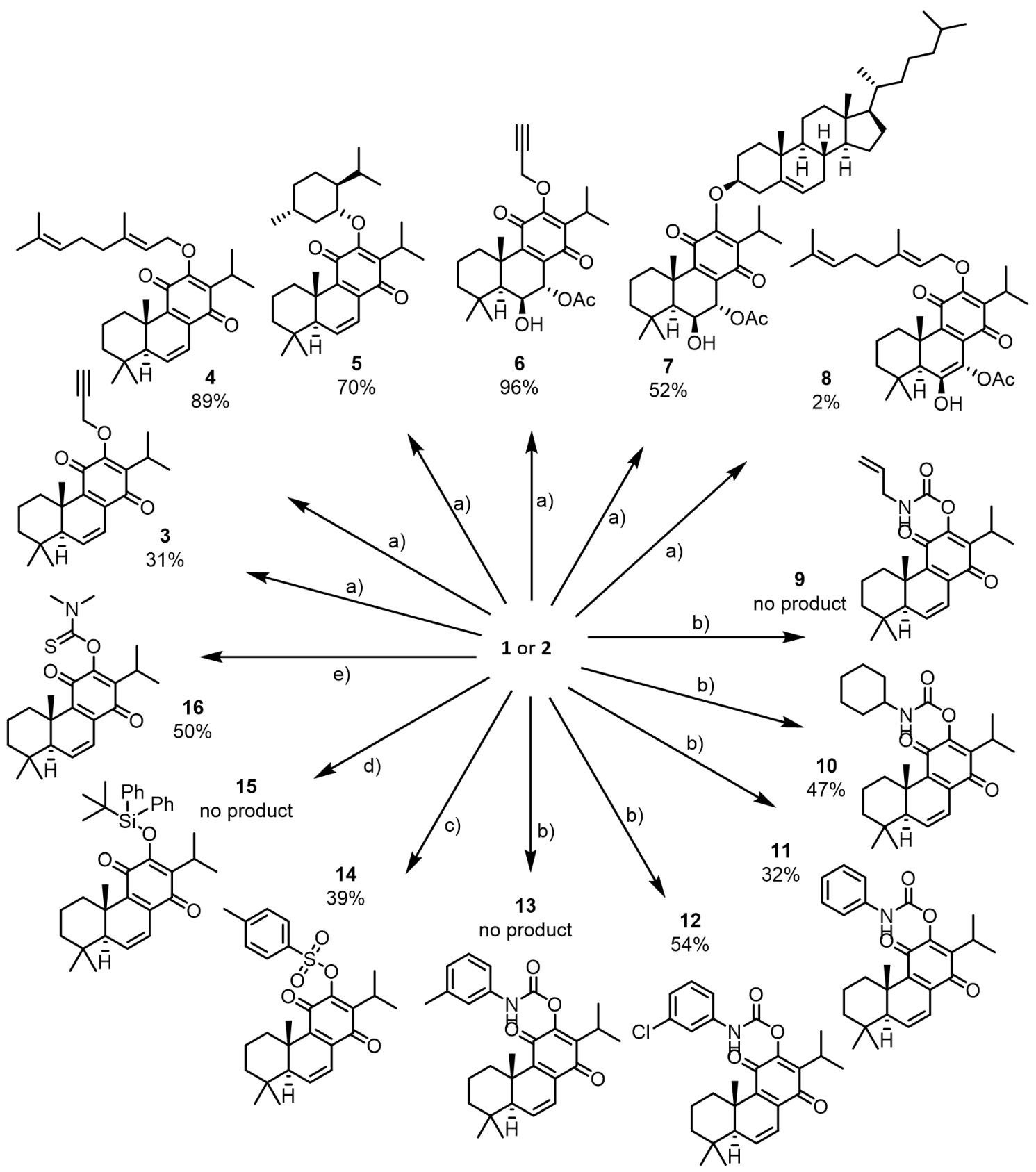

Scheme 1 - Reactions of natural products 1 and $\mathbf{2}$ that produce unstable derivatives: a) Triphenylphosphine (5 eq.), DIAD (5 eq.), corresponding alcohol (5 eq.), and dry THF, under atmosphere inert, derivatives 3 to 8; b) DMAP (5 eq.), corresponding isocyanate (in excess), and dry $\mathrm{CH}_{2} \mathrm{Cl}_{2}$, under inert conditions, expected derivatives 9 to 13; c) triethylamine (4.5 eq.), DMAP (0.3 eq.), $p$-toluenosulfonyl chloride ( 3 eq.), and dry $\mathrm{CH}_{2} \mathrm{Cl}_{2}$, derivative 14; d) imidazole (2 eq.), TBDPSCl (in excess), and dry $\mathrm{CH}_{2} \mathrm{Cl}_{2}$, expected derivative 15; e) dimethylthiocarbamoyl chloride (1.2 eq.), $\mathrm{NaH}$ (1 eq), $\mathrm{NaI}(0.5$ eq.), and THF, derivative 16.

Esquema 1 - Reações dos produtos naturais 1 e $\mathbf{2}$ que conduziram a derivados instáveis: a) Trifenilfosfina (5 eq.), DIAD (5 eq.), álcool correspondente (5 eq.) e THF seco, sob atmosfera inerte, derivados 3 to 8; b) DMAP (5 eq.), isocianato correspondente (em excesso) e $\mathrm{CH}_{2} \mathrm{Cl}_{2}$ seco, sob atmosfera inerte, derivados esperados 9 to 13 ; c) triethilamina (4.5 eq.), DMAP (0.3 eq.), cloreto de $p$-toluenosulfonil ( 3 eq.) e $\mathrm{CH}_{2} \mathrm{Cl}_{2}$ seco, derivado 14; d) imidazole (2 eq.), TBDPSCl (em excesso) e $\mathrm{CH}_{2} \mathrm{Cl}_{2}$ seco, derivado esperado 15; e) cloreto de dimetiltiocarbamoilo (1.2 eq.), $\mathrm{NaH}$ (1 eq), $\mathrm{NaI}$ (0.5 eq.) e THF, derivado 16. 


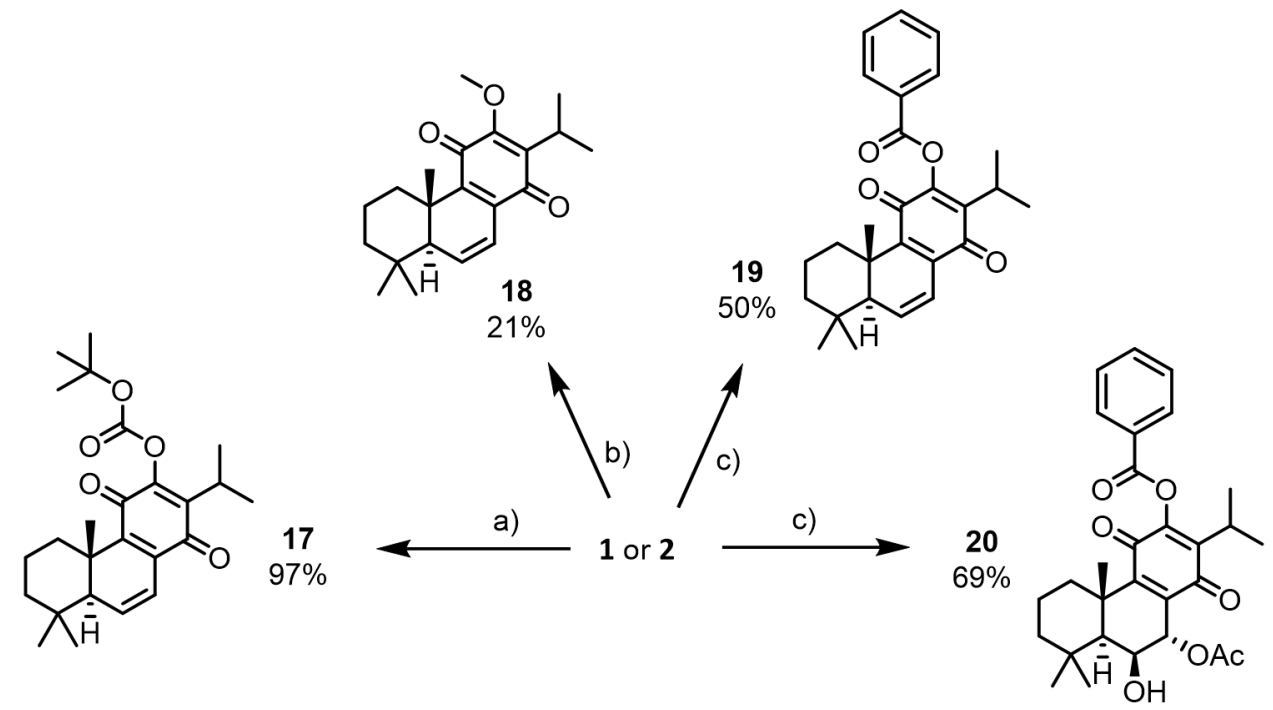

Scheme 2 - Reactions of 1 and 2 that afford stable derivatives: a) DMAP (0.5 eq.), Boc ${ }_{2} \mathrm{O}$ (2.2 eq.), and dry CH${ }_{2} \mathrm{Cl}_{2}$, derivative 17; b) $\mathrm{CH}_{3} \mathrm{I}$ (8.4 eq.), $\mathrm{Ag}_{2} \mathrm{O}$ (8.4 eq.), and dry $\mathrm{CH}_{2} \mathrm{Cl}_{2}$, derivative 18; c) Pyridine (12 eq.), benzoyl chloride (12 eq.), and dry $\mathrm{CH}_{2} \mathrm{Cl}_{2}$, derivatives 19 and $\mathbf{2 0}$.

Esquema 2 - Reações de 1 e 2 que originaram derivados estáveis: a) DMAP (0.5 eq.), Boc $2 \mathrm{O}$ (2.2 eq.) e $\mathrm{CH}_{2} \mathrm{Cl}_{2}$ seco, derivado 17; b) $\mathrm{CH}_{3} \mathrm{I}$ (8.4 eq.), $\mathrm{Ag}_{2} \mathrm{O}$ (8.4 eq.) e $\mathrm{CH}_{2} \mathrm{Cl}_{2}$ seco, derivado 18; c) Piridina (12 eq.), cloreto de benzoilo (12 eq.) e $\mathrm{CH}_{2} \mathrm{Cl}_{2}$ seco, derivados 19 e 20.

Assessment of preliminary toxicity - Brine shrimp lethality bioassay

Samples of each tested compound were prepared at a concentration of $100 \mathrm{ppm}$ in a salt medium (Brine shrimp salt obtained from JBL GmbH and Co. KG, D-67141, Neuhofen Germany) at a concentration of $35 \mathrm{~g} / \mathrm{L}$. A 24-well plate was used, and around 10 to 15 larvae were added to each well containing salt medium. Afterward, each compound was added $(100 \mu \mathrm{L})$ to the corresponding wells, and the plate was stored for $24 \mathrm{~h}$ at $25^{\circ} \mathrm{C}$. After $24 \mathrm{~h}$, the number of dead larvae in each well was recorded. To determine the total number of larvae in each well, death was induced on the remaining living larvae by adding potassium dichromate $\left(\mathrm{K}_{2} \mathrm{Cr}_{2} \mathrm{O}_{7}\right)$ at 1 $\mathrm{mg} / \mathrm{mL}$.

After $24 \mathrm{~h}$, all dead larvae were counted and the mortality rate (\%) was determined according to Equation 1. Dimethyl sulfoxide (DMSO) at the same concentration of the samples (100 ppm) was used as a negative control. Four replicates were used for each test, and the assay was performed in triplicate.

Mortality Rate $(\%)=$

$\frac{(\text { Total A. salina }- \text { Living A. salina })}{(\text { Total } A \text {. salina })} \times 100$

[Eq. 1]
Avaliação da toxicidade geral-Bioensaio de letalidade de Artémia

As amostras analisadas foram preparadas a uma concentração de 100 ppm, em meio salino (Sal para camarão marinho adquirido a JBL $\mathrm{GmbH}$ and Co. KG, D-67141 Neuhofen, Alemanha) à concentração de $35 \mathrm{~g} / \mathrm{L}$. Numa placa de 24 poços, colocaram-se aproximadamente 10 a 15 larvas, em meio salino, em cada poço. De seguida, cada composto foi adicionado $(100 \mu \mathrm{L})$ ao poço correspondente e a placa armazenada por $24 \mathrm{~h}$ a $25^{\circ} \mathrm{C}$. Após $24 \mathrm{~h}$, o número de larvas mortas em cada poço foi registado. De modo a determinar o número total de larvas em cada poço, a morte das larvas vivas remanescentes foi induzida, pela adição de dicromato de potássio $\left(\mathrm{K}_{2} \mathrm{Cr}_{2} \mathrm{O}_{7}\right)$ a $1 \mathrm{mg} / \mathrm{mL}$.

Após $24 \mathrm{~h}$, todas as larvas mortas foram contadas e a taxa de mortalidade (\%) determinada de acordo com a Equação 1. O controlo negativo utilizado foi o dimetilssulfóxido (DMSO), na mesma concentração das amostras (100 ppm). Quatro réplicas foram usadas para cada teste, e o ensaio foi realizado em triplicado.

Taxa de letalidade $(\%)=$

$\underline{\text { (A. salina total }- \text { A. salina vivos) }} \times 100$

[Eq. 1] 


\section{Statistical Analysis}

The results were expressed as the mean value \pm SD. Comparisons were performed within groups by the analysis of variance using the ANOVA test. Significant differences between control and experimental groups were assessed by the SigmaStat software (StatSoft, Tulsa, OK, USA). A probability level $p<0.05$ was considered to indicate statistical significance.

\section{Results and discussion}

\section{Hemi-synthesis of royleanone derivatives}

Several hemi-synthetic reactions were performed to prepare a small library of compounds of enhanced cytotoxic potential. Both natural compounds $\mathbf{1}$ and $\mathbf{2}$ (Figure 1) were subjected to short-time microwaveassisted Mitsunobu and benzoylation reactions. Natural compound $\mathbf{2}$ was also subjected to a carbamoylation, tosylation, methylation, and introduction of Boc (tertbutyloxycarbonyl) and TBDPS (tert-butyldiphenylsilyl) groups. The predicted structures and the isolated derivatives (3 to 20) are shown in Schemes1 and 2.

The introduction of Boc group (17), methylation (18), and benzoylation (19 and 20) reactions were accomplished with success, affording pure products with overall good yields (97\% for derivative 17, 28\% for methylated derivative 18, and $50 \%$ and $69 \%$ for benzoylated derivatives 19 and 20, respectively), scheme 2. Unfortunately, products 3 to $\mathbf{1 6}$ (Scheme 1) displayed a high rate of decomposition, occurring especially after isolation.

\section{Evaluation of general toxicity using A. salina model}

Although some of the expected derivatives were not formed due to their chemical (in)stability, the general toxicity of all the obtained derivatives was assessed. The general toxicity was assessed through the brine shrimp lethality bioassay. Figure 2 illustrates the mortality rate (\%) of $A$. salina after $24 \mathrm{~h}$ of exposure to the diterpenoid compounds tested.

According to the results, natural product 1 displays moderate toxic activity $(36.68 \%$ at $100 \mathrm{ppm})$. The unstable tosylation derivative (9) presented the highest mortality rate $(81.87 \%)$. Overall, in agreement with this model, the chemical modifications induced in natural royleanone 1 structure through microwave-assisted Mitsunobu reactions, enhanced the toxic activity in all derivatives ( $\mathbf{3}$ to $\mathbf{5}$ ). Likewise, stable methylated $\mathbf{1 8}$ and

\section{Análise Estatística}

Os resultados foram expressos como valores médios \pm desvios padrão. As comparações foram realizadas dentro dos grupos pela análise de variância, utilizando o teste ANOVA. As diferenças significativas entre os grupos controlo e experimental foram avaliadas pelo software SigmaStat (StatSoft, Tulsa, OK, EUA). O nível de significância $p<0,05$ foi considerado para indicar significância estatística.

\section{Resultados e discussão}

\section{Hemi-sintese de derivado de royleanone}

Diversas reações hemi-sintéticas foram realizadas com o objetivo de preparar uma pequena biblioteca de compostos com elevado potencial citotóxico. Os compostos naturais 1 e $\mathbf{2}$ (Figura 1) foram submetidos a reações de Mitsunobu, assistidas por microondas, e de benzoilação. Reações de carbamoilação, tosilação, metilação e introdução dos grupos Boc (terc-butiloxicarbonil) e TBDPS (terc-butildifenilsilil) também foram testadas no composto 2 . As estruturas previstas e os derivados isolados (3 a $\mathbf{2 0}$ ) estão apresentados nos Esquemas 1 e 2.

As reações de introdução do grupo Boc (17), metilação (18) e benzoilação (19 e 20) originaram produtos puros com bons rendimentos gerais $(97 \%$ para o derivado $17,28 \%$ para o derivado metilado 18 e $50 \%$ e $69 \%$ para os benzoilados 19 e $\mathbf{2 0}$, respetivamente), Esquema 2. Infelizmente, os produtos 3 a $\mathbf{1 6}$ (Esquema 1) apresentaram uma elevada taxa de decomposição, ocorrendo especialmente após o isolamento.

Avaliação da toxicidade geral através do ensaio de letalidade de A. salina

Alguns dos derivados esperados não se formaram devido à sua instabilidade química. No entanto, avaliouse a toxicidade geral de todos os derivados obtidos. A toxicidade geral foi avaliada através do bioensaio de letalidade de artémia. A Figura 2 ilustra a taxa de mortalidade (\%) de A. salina após $24 \mathrm{~h}$ de exposição aos diterpenóides.

De acordo com os resultados apresentados, o produto natural 1 apresenta uma atividade tóxica moderada (36.68\% à concentração de 100 ppm). O derivado tosilado instável (9) é responsável pela taxa de mortalidade mais elevada do ensaio $(81.87 \%)$. 
benzoylated 19 derivatives increased the toxicity of the original scaffold (1). The derivatives 9 - 11, 10, and 11 displayed the lowest mortality rate.

Natural royleanone $\mathbf{2}$ appears to be slightly less toxic than 1 (30.95\% at $100 \mathrm{ppm})$, but similarly, the Mitsunobu derivatives increased the toxicity of the lead molecule (compounds $\mathbf{6}$ to $\mathbf{8}$ ). The benzoylated product of $\mathbf{2}$ (compound 20) also slightly increased the toxicity of the original scaffold.

Considering that only derivatives $\mathbf{1 7}$ to $\mathbf{2 0}$ were stable, that $\mathbf{1 8}$ was obtained with a lower yield, and that $\mathbf{1 7}$ displayed lower toxicity, this shows that compounds 19 and 20 (both esters) were the most promising of the targets produced.
De um modo geral, as modificações induzidas na estrutura do composto natural 1, por reações de Mitsunobu assistidas por micro-ondas, conduziram a um aumento da toxicidade em todos os derivados (3 to 5). Do mesmo modo, os derivados estáveis $\mathbf{1 8}$ (metilado) e 19 (benzoilado) aumentaram a toxicidade verificada no composto de partida (1). Os derivados 9 11, 10 e 11 apresentaram a menor taxa de mortalidade.

A roileanona natural $\mathbf{2}$ apresenta valores de toxicidade ligeiramente inferiores a 1 (30.95\% à concentração de100 ppm). À semelhança do que se verificou com 1, os derivados de Mitsunobu (compostos 6 a 8) obtidos a partir de $\mathbf{2}$ foram responsáveis por um aumento da toxicidade comparativamente com ao composto de partida. Adicionalmente, o produto benzoilado de $\mathbf{2}$ (composto 20) aumentou ligeiramente a toxicidade verificada em 2.

Considerando que apenas os derivados $\mathbf{1 7}$ a $\mathbf{2 0}$ são estáveis, o derivado 18 foi obtido com baixo rendimento e o 17 apresentou baixa toxicidade, os resultados demonstram que os compostos $\mathbf{1 9}$ e $\mathbf{2 0}$ (ambos ésteres) são os mais promissores.

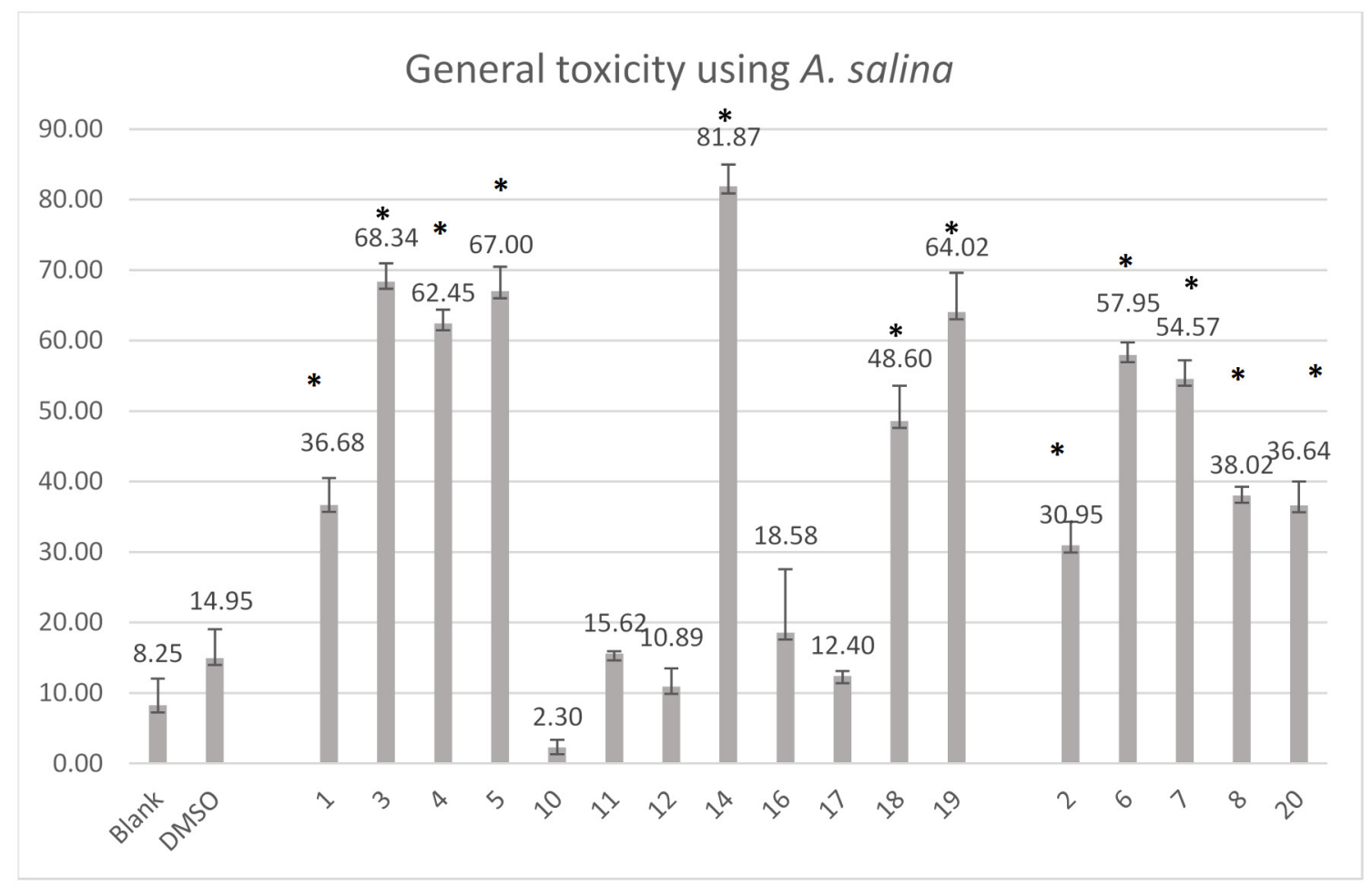

Figure 2 - Mortality rate (\%) of Artemia salina after $24 \mathrm{~h}$ exposure to royleanones. Values are expressed as the mean $\pm \mathrm{SD}(\mathrm{n}=3) .{ }^{*} p<0.05$ comparison DMSO vs compounds.

Figura 2 -Taxa de letalidade (\%) de Artemia salina após 24 h de exposição às roileanonas. Os valores são expressos como a média \pm DP $(\mathrm{n}=3){ }^{*} p<0,05$ comparação DMSO vs compostos. 


\section{Conclusions}

The reactivity of two natural royleanones $\mathbf{1}$ and $\mathbf{2}$ was explored. Several hemi-synthetic reactions were performed, and the obtained products were limited by stability issues: the derivatives $\mathbf{3}$ to $\mathbf{1 6}$ tend to degrade after isolation. Successful results were obtained when performing methylation and benzoylation, as with the introduction of a BOC group, affording pure compounds (17 to $\mathbf{2 0}$ ), with overall good yields.

General toxicity using the $A$. salina model has been established for the obtained products. As such, products $\mathbf{3}$ to $\mathbf{8}, \mathbf{1 4}$, and $\mathbf{1 8}$ to $\mathbf{2 0}$ have increased the toxicity of the lead compound. Products $\mathbf{1 9}$ and $\mathbf{2 0}$ displayed the best results regarding their stability and high toxicity, thus suggesting that the formation of esters is a more convenient approach for future derivatives.

\section{Authors Contributions Statement}

EN, VI - experimental and original writing; AD visualisation; CA - methodology, supervision; PR conceptualization, supervision, final writing

\section{Funding}

Support for this work was provided by Fundação para a Ciência e a Tecnologia (FCT) through projects UIDP/04567/2020 e UIDB/04567/2020 and $\mathrm{PhD}$ grant SFRH/BD/137671/2018.

\section{Conflict of Interest}

The authors report no conflicts of interest.

\section{Conclusões}

A reatividade de duas roileanonas naturais $\mathbf{1}$ e $\mathbf{2}$ foi estudada através de várias reações hemi-sintéticas. Os produtos obtidos apresentaram alguns problemas de estabilidade: os derivados $\mathbf{3}$ a $\mathbf{1 6}$ degradaram no processo de isolamento. No entanto foram obtidos produtos puros e estáveis, com bons rendimentos globais, nas reações de metilação, benzoilação e introdução do grupo BOC (17 a 20).

A toxicidade geral através do modelo de $A$. salina foi avaliada para os derivados preparados. Os derivados 3 a 8,14 e 18 a 20 aumentaram a toxicidade do composto natural de partida. Os produtos 19 e 20 apresentaram os melhores resultados quanto à estabilidade e elevada toxicidade, sugerindo que a formação de ésteres é uma abordagem mais conveniente para futuros derivados.

\section{Declaração Sobre as Contribuições do Autor}

EN, VI - experimental e escrita original; AD - visualisação; CA - metodologia, supervisão; PR - concepção, supervisão, edição final

\section{Financiamento}

Os autores agradecem à FCT pelo apoio financeiro para este trabalho através dos projetos UIDP/04567/2020 e UIDB/04567/2020 e bolsa de Doutoramento SFRH/ $\mathrm{BD} / 137671 / 2018$.

\section{Conflito de Interesses}

Os autores não têm conflitos de interesse a reportar. 


\section{References / Referências}

1. World Health Organization (WHO), fact sheet on Cancer. Available online: https://www.who.int/news-room/fact-sheets/ detail/cancer (accessed on 5 February 2021).

2. Tobore T. O. (2019). On the need for the development of a cancer early detection, diagnostic, prognosis, and treatment response system. Future science OA, 6(2), FSO439. https://doi.org/10.2144/fsoa-2019-0028

3. Nobili, S., Lippi, D., Witort, E., Donnini, M., Bausi, L., Mini, E., \& Capaccioli, S. (2009). Natural compounds for cancer treatment and prevention. Pharmacological research, 59(6), 365-378. https://doi.org/10.1016/j.phrs.2009.01.017

4. Taviano, M. F., Rashed, K., Filocamo, A., Cacciola, F., Dugo, P., Mondello, L., Bisignano, C., Acquaviva, R., D'Arrigo, M., \& Miceli, N. (2018). Phenolic profile and biological properties of the leaves of Ficus vasta Forssk. (Moraceae) growing in Egypt. BMC complementary and alternative medicine, 18(1), 161. https://doi.org/10.1186/s12906-018-2210-0

5. Seca, A., \& Pinto, D. (2018). Plant Secondary Metabolites as Anticancer Agents: Successes in Clinical Trials and Therapeutic Application. International journal of molecular sciences, 19(1), 263. https://doi.org/10.3390/ijms19010263

6. Zhang, Y., Mu, J., Han, J., \& Gu, X. (2012). An improved brine shrimp larvae lethality microwell test method. Toxicology mechanisms and methods, 22(1), 23-30. https://doi.org/10.3109/15376516.2011.583297.

7. Papadopoulos, A.I.; Lazaridou, E.; Mauridou, G.; Touraki, M. (2004). Glutathione S-transferase in the branchiopod Artemia salina. Marine Biology, 144, 295-301, doi:10.1007/s00227-003-1203-8.

8. Ntungwe N, E., Domínguez-Martín, E. M., Roberto, A., Tavares, J., Isca, V., Pereira, P., Cebola, M. J., \& Rijo, P. (2020). Artemia species: An Important Tool to Screen General Toxicity Samples. Current pharmaceutical design, 26(24), 2892-2908. https://doi.org/10 .2174/1381612826666200406083035

9. Libralato, G.; Prato, E.; Migliore, L.; Cicero, A.M.; Manfra, L. (2016) A review of toxicity testing protocols and endpoints with Artemia spp. Ecological Indicators, 69, 35-49, doi:10.1016/j.ecolind.2016.04.017.

10. Ntungwe N, E.; Marçalo, J.; Garcia, C.; Reis, C.; Teodósio, C.; Oliveira, C.; Oliveira, C.; Roberto, A. (2017) Biological activity screening of seven Plectranthus species. Biomedical and Biopharmaceutical Research, 14(1), 95-108, doi:10.19277/BBR.14.1.153.

11. Zengin, G., Ferrante, C., Senkardes, I., Gevrenova, R., Zheleva-Dimitrova, D., Menghini, L., Orlando, G., Recinella, L., Chiavaroli, A., Leone, S., Brunetti, L., Picot-Allain, C., Rengasamy, K. R., \& Mahomoodally, M. F. (2019). Multidirectional biological investigation and phytochemical profile of Rubus sanctus and Rubus ibericus. Food and chemical toxicology : an international journal published for the British Industrial Biological Research Association, 127, 237-250. https://doi.org/10.1016/j.fct.2019.03.041.

12. Krstić, N. M., Matić, I. Z., Juranić, Z. D., Novaković, I. T., \& Sladić, D. M. (2014). Steroid dimers-in vitro cytotoxic and antimicrobial activities. The Journal of steroid biochemistry and molecular biology, 143, 365-375. https://doi.org/10.1016/j.jsbmb.2014.06.005

13. Olivares-Bañuelos, T., Gutiérrez-Rodríguez, A. G., Méndez-Bellido, R., Tovar-Miranda, R., Arroyo-Helguera, O., Juárez-Portilla, C., Meza-Menchaca, T., Aguilar-Rosas, L. E., Hernández-Kelly, L., Ortega, A., \& Zepeda, R. C. (2019). Brown Seaweed Egregia menziesii's Cytotoxic Activity against Brain Cancer Cell Lines. Molecules (Basel, Switzerland), 24(2), 260. https://doi.org/10.3390/ molecules 24020260

14. Logarto Parra, A., Silva Yhebra, R., Guerra Sardiñas, I., \& Iglesias Buela, L. (2001). Comparative study of the assay of Artemia salina L. and the estimate of the medium lethal dose (LD50 value) in mice, to determine oral acute toxicity of plant extracts. Phytomedicine : international journal of phytotherapy and phytopharmacology, 8(5), 395-400. https://doi.org/10.1078/0944-7113-00044.

15. Gajardo, G. M., \& Beardmore, J. A. (2012). The brine shrimp Artemia: adapted to critical life conditions. Frontiers in physiology, 3 , 185. https://doi.org/10.3389/fphys.2012.00185.

16. Arslanyolu, M.; Erdemgil, F.Z.(2006) Evaluation of the AntibacterialActivity and Toxicity of Isolated Arctiin From the Seeds of Centaurea Sclerolepis, Journal of Faculty of Pharmacy of Ankara University, 35 (2), 103-109. https://doi.org/10.1501/Eczfak_0000000052

17. Mayorga, P., Pérez, K. R., Cruz, S. M., \& Cáceres, A. (2010). Comparison of bioassays using the anostracan crustaceans Artemia salina and Thamnocephalus platyurus for plant extract toxicity screening. Revista Brasileira de Farmacognosia, 20(6), 897-903. https:// dx.doi.org/10.1590/S0102-695X2010005000029.

18. Logarto Parra, A., Silva Yhebra, R., Guerra Sardiñas, I., \& Iglesias Buela, L. (2001). Comparative study of the assay of Artemia salina L. and the estimate of the medium lethal dose (LD50 value) in mice, to determine oral acute toxicity of plant extracts. Phytomedicine : international journal of phytotherapy and phytopharmacology, 8(5), 395-400. https://doi.org/10.1078/0944-7113-00044.

19. Garcia, C., Silva, C. O., Monteiro, C. M., Nicolai, M., Viana, A., Andrade, J. M., Barasoain, I., Stankovic, T., Quintana, J., Hernández, I., González, I., Estévez, F., Díaz-Lanza, A. M., Reis, C. P., Afonso, C. A., Pesic, M., \& Rijo, P. (2018). Anticancer properties of the abietane diterpene 6,7-dehydroroyleanone obtained by optimized extraction. Future medicinal chemistry, 10(10), 1177-1189. https:// doi.org/10.4155/fmc-2017-0239.

20. Bernardes, C., Garcia, C., Pereira, F., Mota, J., Pereira, P., Cebola, M. J., Reis, C. P., Correia, I., Piedade, M., Minas da Piedade, M. E., \& Rijo, P. (2018). Extraction Optimization and Structural and Thermal Characterization of the Antimicrobial Abietane 7 $\alpha$-Acetoxy-6 $\beta$ hydroxyroyleanone. Molecular pharmaceutics, 15(4), 1412-1419. https://doi.org/10.1021/acs.molpharmaceut.7b00892.

21. Garcia, C., Isca, V., Pereira, F., Monteiro, C. M., Ntungwe, E., Sousa, F., Dinic, J., Holmstedt, S., Roberto, A., Díaz-Lanza, A., Reis, C. P., Pesic, M., Candeias, N. R., Ferreira, R. J., Duarte, N., Afonso, C., \& Rijo, P. (2020). Royleanone Derivatives From Plectranthus spp. as a Novel Class of P-Glycoprotein Inhibitors. Frontiers in pharmacology, 11, 557789. https://doi.org/10.3389/fphar.2020.557789

22. Bessa, C., Soares, J., Raimundo, L., Loureiro, J. B., Gomes, C., Reis, F., Soares, M. L., Santos, D., Dureja, C., Chaudhuri, S. R., LopezHaber, C., Kazanietz, M. G., Gonçalves, J., Simões, M. F., Rijo, P., \& Saraiva, L. (2018). Discovery of a small-molecule protein kinase $\mathrm{C} \delta$-selective activator with promising application in colon cancer therapy. Cell death \& disease, 9(2), 23. https://doi.org/10.1038/ s41419-017-0154-9. 